INTERNATIONAL BULLETIN OF BACTERIOLOGICAL NOMENCLA TURE AND TAXONOMY
Vol. 8, Nos. 3-4
October 15, 1958
pp. $181-183$

\title{
REPORT OF THE SUBCOMMITTEE ON THE FANILY NEISSERIACEAE
}

This report consists of two items. The first is a final report on our study of the classification of the meningococcus, Neisseria meningitidis, and our recommendation concerning it. The second concerns the future of the subcommittee.

At the $V$ International Congress for Microbiology in Rio de Janeiro, 1950, the Subcomittee on the Family Neisseriaceae presented a preliminary report in which its members proposed a classification of Neisseria meningitidis into Groups A, B, C, and D, following the recommendations of the International Code of Nomenclature. This was done because there was considerable confusion in the designation used and the need for uniformity in this respect was felt by workers in that field.

At the time of the VI Congress in Rome, 1953, the Proceedings of the Rio Congress had not been published. Hence, bacteriologists had had little opportunity to become familiar with this recommended classification of the meningococcus. Individual workers here and there had found it very workable.

In April, 1954, this recommended classification was published in the International Bulletin of Bacteriological Nomenclature and Taxonomy. Since that time this classification has attained wide use, and has found its way into several well-known text and reference books. For example, it has been adopted in the seventh edition of Bergey's Manual of Determinative Bacteriology, and is described in the latest ( $4 \mathrm{th}$ ) edition of the Topley and Wilson comprehensive text edited by Wilson and Miles, and in the lith edition of Zinsser's Textbook of Bacteriology by Smith and Conant. The use of this recommended A B C D classification is growing and seems to be meeting with satisfaction among those who use it. We therefore recommend this classification of $\underline{N}$. meningit idis to the International Committee on Bacteriological Nomenclature. The accompanying Table shows the relation of this classification to those that have been used in the past. In presenting this classification we realize that no such study is either perfect or finished, but it gives us a good working 
RELATIONSHIPS AMONG THE VARIOUS CLASSIFICATIONS OF MENINGOC $\cong C I$

\begin{tabular}{|c|c|c|c|c|c|c|}
\hline $\begin{array}{l}\text { Dopter } \\
\text { a nd } \\
\text { Pa uron, } \\
1914 \\
\end{array}$ & $\begin{array}{l}\text { Gordon } \\
\text { and } \\
\text { Murray, } \\
1915\end{array}$ & $\begin{array}{l}\text { Griffith; } \\
\text { Sc ott, } \\
1916 \\
\end{array}$ & $\begin{array}{l}\text { Nicolle, } \\
\text { De bains, } \\
\text { and } \\
\text { Jolan, } \\
1918\end{array}$ & $\begin{array}{l}\text { Eva ns } \\
\text { (Tropin } \\
\text { Groups), } \\
1920 \\
\end{array}$ & $\begin{array}{l}\text { Common } \\
\text { use } \\
1940 \\
\end{array}$ & $\begin{array}{l}\text { Rec ommended } \\
\text { by Committee } \\
1950\end{array}$ \\
\hline Mening oc occus & $\begin{array}{r}\text { I } \\
\text { II I }\end{array}$ & I & A & $\mathrm{R}$ & I & A \\
\hline \multirow[t]{4}{*}{ Pa ra-men ingoc occus } & II & II & B & S & I I & B \\
\hline & IV & & & Z & IV & D \\
\hline & & & C & & II a lpha & C \\
\hline & & & $D^{*}$ & & & \\
\hline
\end{tabular}

* Re lation of this $D$ to other groups is unknown. 
basis for use today. This is the final report on the classification of the meningococcus by this group.

The second item which we would like to lay before your Committee is the question of our continuance. Several of the original members have died, and same others have retired from active work, or have gone into other fields. Less than half of the original group is now actually interested in this sphere of activity.

There is, however, cansiderable work being done outside of our Subcommittee on various species of the Family Neisseriaceae. Although not primarily taxonomic, the information being gained makes a fundamental background for the study of relationships. Such work is going on in the United States, in Holland, in Scandinavian countries, and in Jugoslavia to our knowledge, and maybe elsewhere. Work is being done on the Veillonellae, on the epidemiological distribution of groups of meningococcus, on the chemistry of the polysaccharides of the serological groups of meningococcus, on metabolic functions and genetic changes in all of the Neisseriae, including the gonococcus. A new field has opened up in finding new species of Neisseria in animals. Some of these younger people would make useful members of our group, and would give its work a new impetus. The names of desirable possible recruits can be given to the Permanent Secretary should the International Committee on Bacteriological Nomenclature decide to continue our Subcomittee on the Neisseriaceae.

Michael J. Pelczar, Secretary

Sara E. Branham, Past Secretary

E.G.D. Murray, Chairman 
